\title{
Transcultural Aspects in Lili Novy's Life and Work
}

\section{Griessler Larina*}

1. University of Ljubljana, The Faculty of Arts, Aškerčeva cesta 2, 1000 Ljubljana, Slovenia

* Correspondence: Larina Griessler; larina.griessler@gmail.com Transcultural aspects in Lili Novy's life and work. Proceedings of Socratic Lectures. 2021; 6: 148-155 https://doi.org/10.55295/PSL.2021.D. 019

Publisher's Note: UL ZF stays neutral with regard to jurisdictional claims in published maps and institutional affiliations.

\section{cc) (i)}

Copyright: $\mathbb{C} 2021$ by the authors. Submitted for possible open access publication under the terms and conditions of the Creative Commons Attribution (CC BY) license (https://creativecommons.org/licenses/b $\mathrm{y} / 4.0 /$ ).

\begin{abstract}
The life and work of the German-Slovenian poet Lili Novy is most often presented in Slovenia in the context of dualism because of her German-Slovenian biography. However, the central thesis is that her life and work should be understood in terms of transculturality, as a meeting place, as an area of interaction, overlapping, intertwining and mutual influence of her two identities and languages, as a process that eludes univocal definitions and requires a different angle of observation. This process and a different angle of observation result in a deeper and better understanding of her self, her essence, her linguistic multi-domain and her (literary) work.
\end{abstract}

Keywords Lili Novy; Transculturality; Poetry; Translation; German-Slovene Literature 


\section{Introduction}

In the fields of research in the humanities and cultural studies, there have been several upheavals and turning points, as new concepts developed in recent decades that triggered a paradigm shift in literary studies (Iljasova-Morger, 2009). In the nineties of the 20th century Wolfgang Welsch (1994) developed the concept of transculturality, which views cultures and their interferences not as isolated and delimited islands, but as a heterogeneous dynamic network. In the present work, it is first explained whether and how the transcultural processes can also be traced in authors with bicultural biographies (Žigon et al., 2020). The lyricist Lili Novy, who had both a German and a Slovenian identity and consequently found artistic expression in both languages (Mugerli, 2003), serves as the object of research. However, the aim of this paper is not to describe Lili Novy's life in detail, nor to present a detailed analysis of her lyrical texts or to search for differences between her German and Slovenian identities regarding the binary concept. Instead, it explores the transcultural elements and traces in Lili Novy's life, in her translational activity and in her poetic work.

\section{The concept of transculturality}

The concept of transculturality has become increasingly established in academic disciplines in recent decades (Iljasova-Morger, 2009). In Germany, the new concept of culture was introduced into the discussion by the German philosopher Wolfgang Welsch in the early 1990s (Iljasova-Morger, 2009). Welsch (1994) describes it as a concept of culture that is not abandoned, but merely reworked and changed by presenting the observer with a completely new perspective. This perspective enables an "integrative understanding of culture" (Welsch, 1995). In his theory, Welsch (1994) sketches a different picture of the relationship between cultures. Not one of isolation and conflict, but one of interweaving and intermingling. It does not promote separation but understanding and interaction. The transculturality concept thus distances itself from the isolation and demarcation of the foreign and the familiar, the foreign culture and the own culture. This creates a new wholeness (Nünning, 2013). The question now arises as to what significance the concept of transculturality has for literary studies and what new perspectives arise from embedding the transcultural discourse in literary studies work. On the one hand, the transcultural process itself is an important starting point: "In this process, which consists of losses, selections, new discoveries and adoptions, the result is something unprecedented." explains Nünning (2013). Literature is thus suitable for the application of the transculturality concept in many ways, since the "unprecedented" (Nünning, 2013; Pfeifer, 1993) can be explored on different levels: on the linguistic, formal and content level - the level of "textual analysis" (Iljasova-Morger, 2009) - and on the level of "literary production and reception" (Iljasova-Morger, 2009). Indeed, literature can also be understood as a transit space where cultural and literary contexts are mixed and interpenetrated through overlaps and entanglements, thereby breaking down any cultural boundaries (Welsch, 1995; Žigon et al., 2020). Literature thus serves as a place where cultural differences are not perceived as problematic or disturbing (Iljasova-Morger, 2009), but as art itself (Žigon et al., 2020). A good example of transcultural analysis is the German-Slovenian lyricist and translator Lili Novy (Figure 1), who never separated her German and Slovenian identities in her life as well as in her lyrical and translational work (Žigon et al., 2020). According to Žigon, Kondrič Horvat and Udovič (Žigon et al., 2020), transcultural identities appear in literary works among authors who have bi- or pluricultural biographies. Indeed, these texts can be understood as interweaving of cultural diversity through which knowledge and understanding of cultural differences and overlaps can be disseminated and preserved (Samide, 2017). The following sections will explore in more detail and explain why addressing "two worlds" (Lončar, 2020), the German and the Slovenian, makes less sense in the case of Lili Novy. 




Figure 1. Lili Novy in her early years. From (Javoršek,1984).

\section{Lili Novy's Life}

The poet Lili Novy was born as Elizabeta Haumeder on 24 December 1885 in Graz. Her father was an Austrian colonel, her mother was Slovenian (Mugerli, 2003). Javoršek (1984) reports that only German was spoken in the aristocratic officer's family, as the mother, Ludovika Ahačič, conversed only with the servants in her mother tongue. After only three years, the family moved to Ljubljana, although it must be emphasised that the new language environment did not yet have any influence on Lili Novy's Slovene language identity (Javoršek,1984). Public life took place in the German language: German was used not only in the higher social circles, but also in schools, offices and in court (Mugerli, 2003). The lyricist's Slovenian language identity only began to develop in Vikrče (Figure 2), a small town northwest of Ljubljana, where she spent most of the summer days of her childhood (Javoršek,1984). It was on her grandfathers' estate that she was first confronted in depth with the Slovenian language (Vidmar, 1979). The children from the village with whom she played conversed with her exclusively in Slovenian, as they did not know German (Javoršek,1984). Lili Novy was therefore not only in a new language environment, but became a part of a different and, for her, completely new cultural environment (Mugerli, 2003).

Life in the countryside was in great contrast to the life she led at home, in the baroque house in Stari trg 11a in Ljubljana (Figure 3) (Mugerli, 2003). There, she received a strict, almost Spartan upbringing that was strongly based on the values and lifestyles of the German-Austrian aristocracy and the militarism of the Habsburg monarchy (Javoršek, 1984). Vikrče, on the other hand, was a place where she could be free of rules and norms and come closer to the Slovenian language and culture (Vidmar, 1979). Nevertheless, her German identity was much more dominant in her teenage years (Mugerli, 2003). 


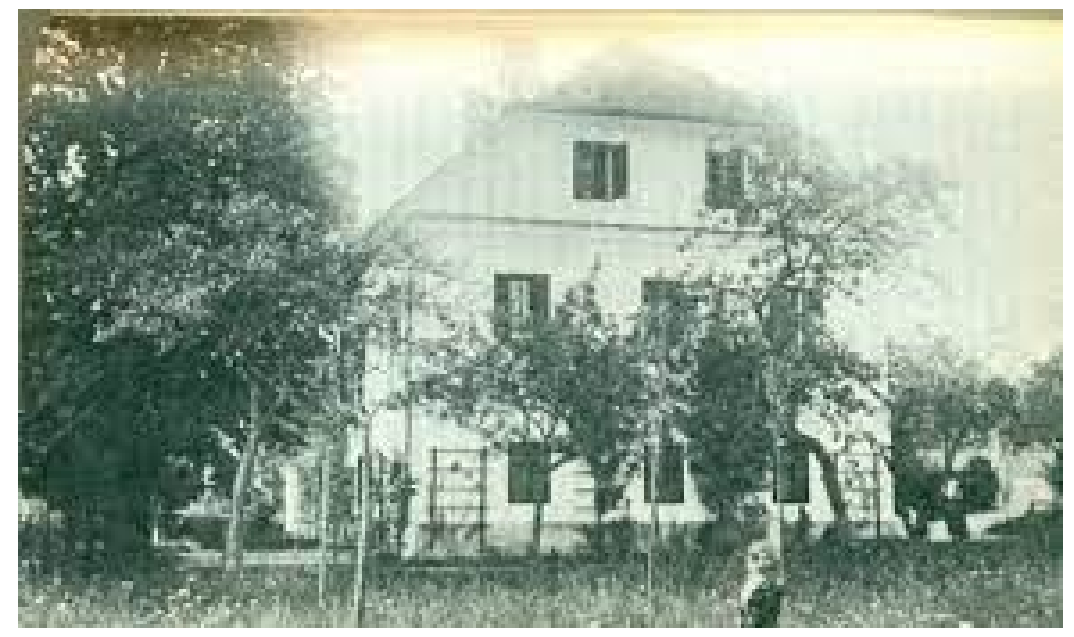

Figure 2. Grandfather's estate in Vikrče (2).

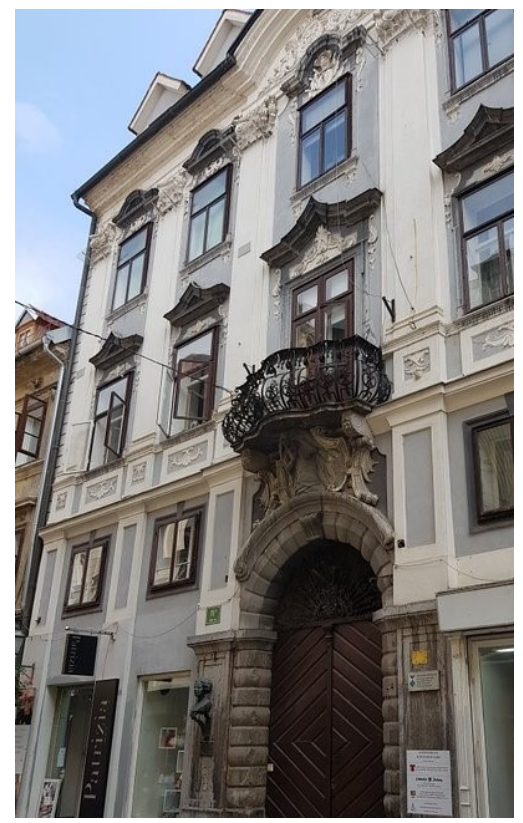

Figure 3. The baroque house in Stari trg 11a, Ljubljana (Tripadvisor, 2022).

\section{Lili Novy's Translation}

She only encountered Slovene literature for the first time after 1919 (Javoršek,1984). Although her translations are often overlooked, they are an important starting point in the poet's life regarding the concept of transculturality (Stančić, 2013). It was through her translations that she made her breakthrough into the Slovenian literary scene, which was becoming more and more established at the time between the two world wars, and was thus an important milestone in the development of her Slovenian identity (Vidmar, 1979). Therefore, translating can be seen as a transit space that enabled her to perceive her Slovenian identity more clearly and to be able to develop it further, which later resulted in overlaps of both cultural worlds (Žigon et al., 2020). But firstly, it is important to under- 
stand what was happening during the Second world war. The news and reports about deportations, forced resettlements, mistreatment, torture and mass murder under the occupying German rule, triggered an inner breakdown in Lili Novy (Javoršek,1984). Although she was never tortured or taken to a concentration camp, she could never really overcome the traumatic experiences of the Second World War (Javoršek,1984). The values and ideals of her German homeland, her belief in humanity, cosmopolitanism, memories of her childhood with which she identified so strongly, were destroyed, resulting in an existential crisis (Javoršek,1984; Mugerli, 2003; Vidmar, 1979). Her German identity was severely violated precisely because of her transcultural biography (Žigon et al., 2020). Although she was unable to write poetry in German for a long time after the war, she did not give up translating (Javoršek,1984). She even started translating from German into Slovenian (Mugerli, 2003). Thus, translation could serve as a kind of healing process to bridge traumatic experiences (Žigon et al., 2020).

\section{Lili Novy's Poetic Work}

In the context of the transculturality concept, Lili Novy's poetic work can also be seen as a whole. Lili Novy began writing her first verses in her youth (Stančić, 2013). She wrote them in German and even in French (Javoršek,1984). In the years that followed, German remained the language of her artistic expression (Vidmar, 1979). In these poems she expressed her thoughts about transience, loneliness, pain, loss, love, nature, life and death (Mugerli, 2003). Only much later, in her more mature years, she began to write poetry in the Slovenian language (Javoršek, 1984) (Figure 4). She did not write in German or Slovenian to pursue ideological or national goals, but to enter new spaces through the languages and to find new forms of expression within which she could combine her two identities (Žigon et al., 2020). Indeed, for her, the Slovene language was never a closed space, but a means to live, think and create (Žigon et al., 2020): an important aspect of language in the context of the concept of transculturality (Iljasova-Morger, 2009).

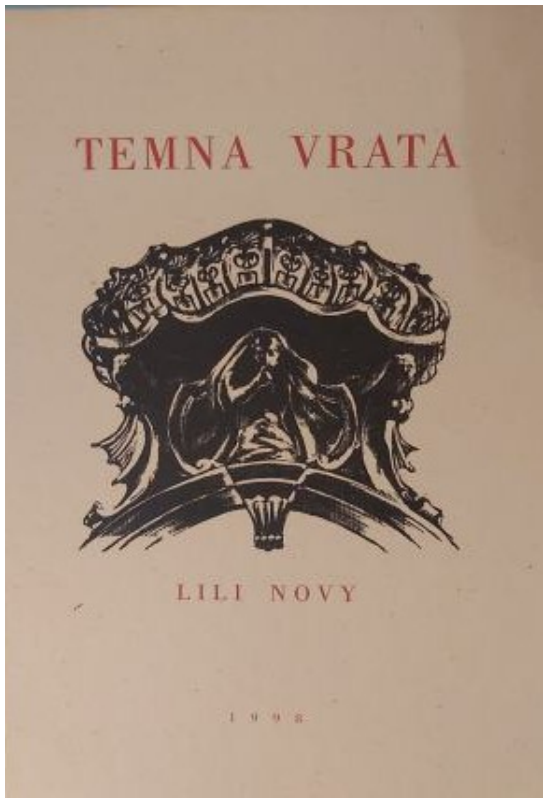

Figure 4. The front page of Lili Novy's first poetry collection in Slovenian language Temna vrata (Novy, 1998).

When asked in which language she preferred to express herself, Lili Novy's grandson Ingo Paš replied that it was not the language that was decisive for the poet, but the "how" and the "what" (Žigon et al., 2020), thus the poetry itself. Indeed, many of her colleagues and researchers, such as Javoršek (1984) or Vidmar (1959; 1979), wrote in their texts that they regretted that Lili Novy's knowledge of Slovenian was insufficient, which is why her poetry contains many outdated or rarely used phrases (Javoršek,1984, 
Vidmar, 1959; 1979). The rhythm and sentence structure are also "unusual" in some poems (Vidmar, 1959). If the alienations are seen as an expression of their transculturality, one can no longer speak of exclusively Slovenian poetry or exclusively German poetry (Žigon et al., 2020). Her art exists precisely in this space of overlaps and intertwining of her two identities or languages, and thus the alienations stand for what her poetry is (Žigon et al., 2020). For in her lyrical texts, the poet interweaves personal experiences and feelings (Mugerli, 2003) as well as experiences from both homelands that have shaped her (Iljasova-Morger, 2009; Žigon et al., 2020), thus linking her original culture with the culture of the country where she later lived (Mugerli, 2003). This can be proven by the following poem "Svit" (Novy, 1998), which creates the strong linguistic effect (Žigon et al., 2020) precisely through the outdated Slovenian formulations and the unusual rhythm (Vidmar, 1959). The beauty of the poem lies in the strangeness of her art.

\section{SVIT}

Roké in usta, pôgled, v mesečini kot sij vodé mehak;

zrak ves lahak,

drgèt rastočih vej, ščebèt $v$ tišini,

srebrn oblak -

Beseda nežna kot dotik nečésa kar pride in zbeži, predrami kri, dotik njen, plah kot ptičjega peresa kot dih noči -

Krajina vsa začarana in druga: nikoli še poprej

biló ni v njej

te ceste, zvezdnobele kot vijuga

do zadnjih mej -

Zrak bolj hladan in proi svit $v$ daljini, neblag, prodiren znak;

korak na tlak

predmestni, trdi. Vso sladkost razblini

okus grenak. -

\section{Conclusions}

Nevertheless, many authors write of the duality in Lili Novy's life (Lončar, 2020), which on closer examination seems less meaningful and is not in harmony with Lili Novy's self-image. In Lili Novy's case, two forms of identity can be identified, the German and the Slovenian identity (Mugerli, 2003), which she skilfully combined by letting them flow together and thereby opening herself up to completely new perspectives (Žigon et al., 2020), which can be seen as a clear element of the transcultural processes (Welsch, 1995). Indeed, Lili Novy understood her different identities not as dividing lines but as points of intersection within which she could express herself and emphasise her artistic self-understanding as a whole (Žigon et al., 2020). Lili Novy never separated her Slovenian and German identities, even more, she even stood out from the nationality labels and rather understood herself as a European, as a world person (Vidmar, 1979). Therefore, the question of which identity she preferred to identify with would not 
be appropriate, as she lived across cultures, beyond any boundaries that could constrict her (Welsch, 1994). Therefore, the transculturality concept is more appropriate for the deeper understanding of Lili Novy than the classical binary system that presents the two identities as isolated, delimited entities (Welsch, 1994, 1995). It is in this context that her translations and poetological work were formed within these two identities that permeated and impacted on her simultaneously (Žigon et al., 2020). Indeed, translating enabled her to perceive her Slovenian identity more clearly (Javoršek,1984), to connect it with the German (Vidmar, 1979) and even to partially overcome the wounded places in her German identity left by the experiences of the Second World War (Samide, 2017). The alienations found in her outdated and unusual formulations (Vidmar, 1959) are not linguistic gaps or errors, but an expression of her art (Žigon et al., 2020). Lili Novy (Figure 5) can therefore be described as a phenomenon in that. In order to intertwine the two identities, she demonstrated a great deal of courage, cosmopolitanism and maturity - and that as a woman.

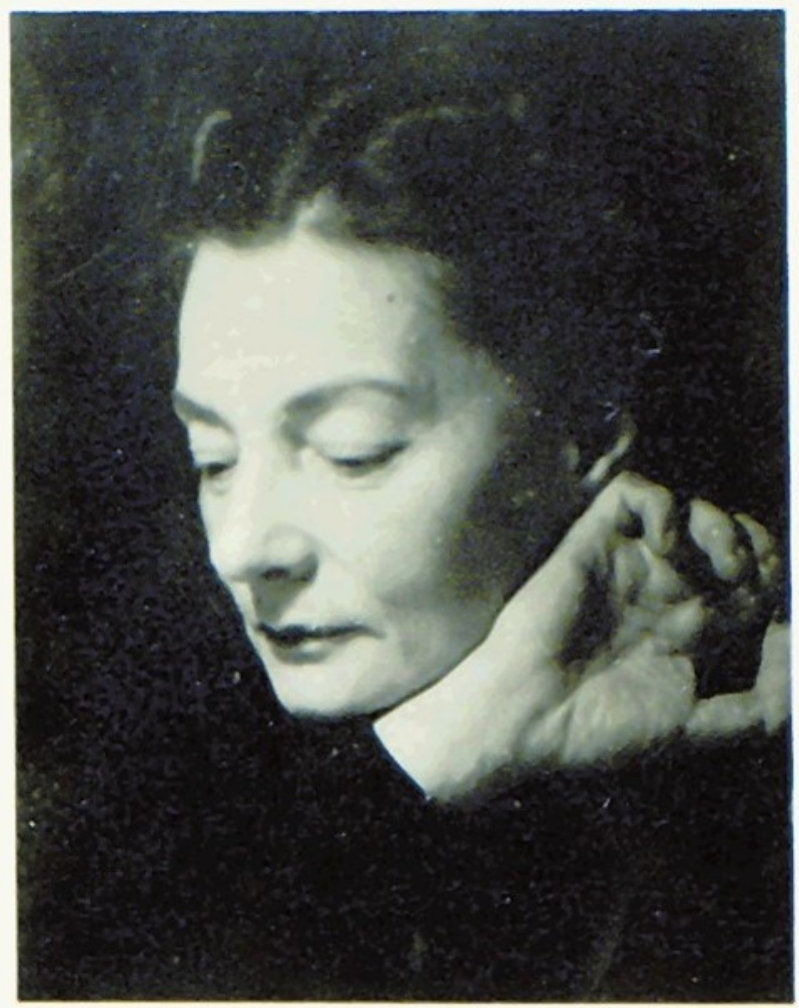

Figure 5. Lili Novy in her later years. From (Javoršek,1984).

\section{Acknowledgements}

The author thanks Irena Samide for the idea to study transcultural aspects in Lily Novy's life and work and for the support in research writing.

Conflicts of Interest: The authors declare no conflict of interest.

\section{References}

1. Iljassova-Morger O. Transkulturalität als Herausforderung für die Literaturwissenschaft und Literaturdidaktik, Das Wort, Ger-manistisches Jahrbuch Russland 2009, pp. 37-57.

2. Javoršek J. Lili Novy. Partizanska knjiga, Ljubljana. 1984.

3. Lončar N. Analiza in recepcija slovenskih pesmi Lili Novy. Diplomsko delo, Filozofska fakulteta Ljubljana. 2020.

4. Mugerli M. Nemške pesmi Lili Novy. Diplomsko delo, Filozofska fakulteta, Ljubljana, 2003, pp. 121.

5. Novy L. Temna vrata. Samozal. D. Petek, Ljubljana. 1998. 
6. Nünning A. (Ed.) Metzler Lexikon. Literatur- und Kulturtheorie. Ansätze - Personen - Kulturbegriffe, Verlag J. B. Metzler, Stuttgart. 2013, pp. 759-760.

7. Pfeifer W. (Ed.) Etymologisches Wörterbuch des Deutschen. Digitalisierte und von Wolfgang Pfeifer überarbeitete Version im Digitalen Wörterbuch der deutschen Sprache. 1993.

8. Samide I. Luiza Pesjak, eine Mittlerin zwischen zwei Welten, (Ed. Kramberger P, Samide I, Žigon T, Und die Brücke hat gezogen, die vom Ost zum West sich schwingt: literarische, kulturelle und sprachliche Vernetzungen und

Grenzüberschreitungen: Festschrift für Mira Miladinović Zalaznik), Znanstvena založba Filozofske fakultete, Ljubljana. 2017, pp. 117-131.

9. Stančić M. Verschüttete Literatur. Die deutschsprachige Dichtung auf dem Gebiet des ehemaligen Jugoslawien von 1800 bis 1945, Böhlau Verlag, Vienna. 2013.

10. Tripadvisor, Schweigerjeva House. Accessed 13.1.2022. Available at https://www.tripadvisor.com/Attraction_Review-g274873-d8261763-Reviews-Schweigerjeva_House-Ljubljana_Upper_Carniol a_Region.html

11. Vidmar J. Oboki: Lili Novy. Državna založba Slovenije, Ljubljana. 1959, pp. 5-26.

12. Vidmar J. Obrazi. Državna založba Slovenije, Ljubljana, 1979.

13. Welsch W. Transkulturalität - die veränderte Verfassung heutiger Kulturen. Ein Diskurs mit Johann Gottfried Herder, VIA REGIA - Blätter für internationale kulturelle Kommunikation. 1994; 20: 1-19.

14. Welsch W. Transkulturalität. Zur veränderten Verfaßtheit heutiger Kulturen, Zeitschrift für Kulturaustausch. 1995; 45: 39-44.

15. Žigon T, Kondrič Horvat V, Udovič B. Vprašanja identitet, migracij in transkulturnosti. Dve domovini. 2020; 51: 185-200. DOI:10.3986/dd.2020.1.11 